14. Чміль Г. П. Екранна культура: плюральність проявів / Харківський держ. педагогічний ун-т ім. Г.С.Сковороди. Харків: Крук, 2003. 336 с.

\title{
References
}

1. Beck, W. (2001). What is globalization? Errors of globalism - the answers to globalization. M.: ProgressTradition [in Russian].

2. Gulimov, A.N. (2011). Screen culture as a form of existence of modern mythology. Knowledge. Understanding. Skill, 1, 252-256 [in Russian].

3. Zubavina, I.B. (2006). Ekranna culture: partly model the art of reality (time and hour at the math). Kiev: Intertekhnologiya [in Ukrainian].

4. Kardenakhlishvili, T.D. Virtualization of modern culture: nature, essence, form of manifestation. URL https://cyberleninka.ru/article/n/virtualizatsiya-sovremennoy-kultury [in Russian].

5. Castells, M. (2000). Information Age: Economy, Society and Culture. M.: State University Higher School of Economics [in Russian].

6. Kurbatov, V.I. (2001). Modern Western Sociology. Analytical review of concepts: studies. allowance. Rostov-on-Don: Phoenix [in Russian].

7. McLuen, M. (2008). Galactica Gutenberg: becoming the people of the Drukovo book. Kiev: Nika-Center [in Russian].

8. Population and Globalization. (2004). Moscow: Nauka [in Russian].

9. Petik, M. (2009). Ukraine in the current globalization processes. Formula rinkovo economics in Ukraine, 19, 530-539 [in Ukrainian].

10. Fistula, I. (2004). Understanding the process of "virtual culture" yak category naukovogo doslidzhennya. Actual problems of history, theory and practice of artistic culture. Vip XII. K.: Mileneum, 83-88 [in Ukrainian]. Russian].

11. Modern philosophical dictionary. (1999). London, Frankfurt am Main, Paris, Moscow, Minsk: Panprint [in

12. Toffler, E. (2010). The Third Wave. Moscow: AST [in Russian].

13. Screen culture - the culture of the XXI century. (2004). Essays on the history of world culture: 4th ed. pererab and add. Tambov: TSTU [in Russian].

14. Chmil, G. P. (2003). Ekranna culture: plurality of manifestations. Kharkov: Kruk [in Ukrainian].

Стаття надійшла до редакиії 20.11.2018 p.

УДК 316.733

\author{
Недзельський Роман Стефанович, \\ здобувач Національної академії керівних кадрів \\ культури і мистецтв \\ ORCID 0000-0001-7229-0906
}

\section{РОЗВИТОК НАЦІОНАЛЬНОГО КУЛЬТУРНОГО ПРОСТОРУ В УМОВАХ ТРАНСФОРМАЦІЙНИХ ЗМІН СУЧАСНОСТІ}

\begin{abstract}
Мета статті - проаналізувати концептуально етапи формування національного культурного простору, 3 огляду на паралелі загальнокультурного світового розвитку. Методологія статті грунтується на міждисциплінарному підході, що передбачає застосування таких наукових методів, як аналіз для розкриття основних елементів формування національного культурного простору; синтез - для обгрунтування особливостей розвитку національного культурного простору в межах конкретної етнонаціональної спільноти. Наукова новизна полягає у дослідженні процесу розвитку етнокультурного простору синхронно процесів загальноцивілізаційного культурного поступу. Висновки. Культура в сучасному суспільстві виступає й усвідомлюється не тільки як результат соціально-економічного та політичного розвитку, а й як необхідна умова, ключовий фактор розвитку, моральний стрижень особистості й суспільства. Як об'єкт державного управління культура - це цілісний комплексний процес, головним орієнтиром якого є людина, іiі безумовний духовний (моральний і інтелектуальний) розвиток і вдосконалення. Адже стан культурного розвитку тієї чи іншої країни є одним із найбільш об'єктивних показників не тільки духовного здоров'я суспільства, але й повноти вирішення тих проблем, в першу чергу, політичних й економічних, які стоять перед ним. Політику держави в галузі культури доцільно розглядати як феномен єднання теорії та практики, що має свої особливості, пов'язані з живим безперервним культурним процесом, спрямованим на адаптацію іiі імперативів до соціокультурних реалій сучасності. Державна культурна політика має охоплювати культурні аспекти всіх державних програм економічного, екологічного, соціального, національного розвитку, а також фактора безпеки держави й особистості. Змістом культурної політики є виявлення пріоритетних напрямів розвитку культури
\end{abstract}

(C) Недзельський Р. С., 2019 
відповідно до визначеного рівня культурного життя та реальних проблем; розроблення або ініціацію відповідно до пріоритетів різноманітних соціокультурних програм; підтримка та реалізація соціокультурних програм шляхом розподілу різного роду ресурсів.

Ключові слова: національний культурний простір, культурна політика, трансформаційні зміни.

Недзельский Роман Стефанович, соискатель Нацчиональной академии руководящих кадров культуры и искусств

Развитие национального культурного пространства в условиях трансформационных изменений современности

Цель статьи - проанализировать концептуально этапы формирования национального культурного пространства, учитывая параллели общекультурного мирового развития. Методология статьи основывается на междисциплинарном подходе, что предусматривает применение таких научных методов, как анализ для раскрытия основных элементов формирования национального культурного пространства; синтез - для обоснования особенностей развития национального культурного пространства в пределах конкретного этнонационального сообщества. Научная новизна заключается в исследовании процесса развития этнокультурного пространства синхронно процессов цивилизационного культурного развития. Выводы. Культура в современном обществе выступает и осознается не только как результат социально-экономического и политического развития, но и как необходимое условие, ключевой фактор развития, нравственный стержень личности и общества. В качестве объекта государственного управления культура - это целостный комплексный процесс, главным ориентиром которого является человек, его безусловный духовное (моральное и интеллектуальное) развитие и совершенствование. Ведь состояние культурного развития той или иной страны является одним из самых объективных показателей не только духовного здоровья общества, но и полноты решения тех проблем, в первую очередь, политических и экономических, которые стоят перед ним. Политику государства в области культуры целесообразно рассматривать как феномен единения теории и практики, имеет свои особенности, связанные с живым культурным процессом, направленным на адаптацию ее императивов к социокультурным реалиям современности. Государственная культурная политика должна охватывать культурные аспекты всех государственных программ экономического, экологического, социального, национального развития, а также фактора безопасности государства и личности. Содержанием культурной политики является выявление приоритетных направлений развития культуры в соответствии с определенным уровнем культурной жизни и реальных проблем; разработку или инициацию в соответствии с приоритетами различных социокультурных программ; поддержка и реализация социокультурных программ путем распределения различного рода ресурсов.

Ключевые слова: национальный культурное пространство, культурная политика, трансформационные изменения.

Nedzelsky Roman, Applicant of the National Academy of Managerial Staff of Cultural and Arts

Development of the national cultural space in the conditions of the transformational changes of the present

The purpose of the article is to analyze conceptually the stages of formation of the national cultural space, taking into account the parallels of the general cultural development of the world. The methodology of the paper is based on an interdisciplinary approach involving the use of such scientific methods as analysis for the disclosure of the basic elements of the formation of a national cultural space; synthesis - to substantiate the peculiarities of the development of the national cultural space within a specific ethno-national community. Scientific novelty consists in the study of the development of the ethnocultural space of synchronous processes of general civilization cultural progress. Conclusions. Culture in today's society is advocated and understood not only as a result of socio-economic and political development, but also as a necessary condition, a key factor of development, the moral core of personality and society. As an object of public administration, culture is an integral complex process, the main guideline of which is a person, its unconditional spiritual (moral and intellectual) development and perfection. After all, the state of cultural development of one or another country is one of the most objective indicators not only of the spiritual health of society, but also the completeness of solving those problems, first of all, political and economic, facing it. The state policy in the field of culture should be regarded as a phenomenon of the unification of theory and practice, which has its own peculiarities connected with a living, continuous cultural process, aimed at adapting its imperatives to the socio-cultural realities of our time. The state cultural policy should cover the cultural aspects of all state programs of economic, ecological, social, national development, as well as the safety factor of state and personality. The content of cultural policy is the identification of the priority directions of cultural development according to a certain level of cultural life and real problems; development or initiation in accordance with the priorities of various socio-cultural programs; support and implementation of socio-cultural programs through the distribution of various kinds of resources.

Key words: national cultural space, cultural policy, transformational changes.

Актуальність теми дослідження. Впродовж історичного розвитку співвідношення соціальних інститутів культури змінювалося залежно від ступеня диференціації суспільного життя і переходу від аграрного до індустріального, згодом - до постіндустріального суспільства. В різні історичні епохи 
існував різний підхід до підтримки культури, а також духовного і художнього виробництва. Скажімо, на ранніх етапах розвитку суспільства, у малодиференційованому соціокультурному середовищі, культурна діяльність ще не виокремлена в самостійну і тому не спирається на особливі соціальні інститути.

У процесі трудової діяльності, побутового спілкування, або ж відповідно до обрядів (народження дитини, брак, смерть, сезонні свята), що склалися, зазвичай відсутній чіткий розподіл на виконавців і слухачів. В архаїчних племінних культурах усі дорослі члени (хоч і розділені на тендерні групи) спільно влаштовують колективні церемонії, а вождь виконує одночасно функції жерця.

Проте і на такому рівні, і в такому середовищі відбувається виділення функціональних "посад" жерця, шамана, ворожбита та знахаря, які виконують особливі функції (хоча переважно "за сумісництвом" з іншими формами діяльності, загальними для решти членів племені). Разом із цим, первинним синкретичним осередком соціалізації є сім'я, в якій батьки і всі дорослі члени так чи інакше вводять підростаюче покоління до кола культурних норм, сенсів, знань і цінностей.

$\mathrm{y}$ подальшому, починаючи зі стародавніх рабовласницьких держав і до сучасних часів, загалом прийнято визначати такі основні типи соціальних інститутів, спрямованих на підтримку культурної сфери:

1) церковний, такий, що спирається на підтримку релігійного інституту;

2) державний, підлеглий централізованому апарату влади;

3) меценатський, або патронажний, при якому знать і заможні люди утримували й одаровували поетів, літераторів, музикантів, архітекторів тощо;

4) ремісничий (підприємницький), коли предмет прикладного або монументального мистецтва виготовлявся на місцевий ринок або на замовлення;

5) комерційний, такий, що виникає вже в доіндустріальному суспільстві та пов'язаний 3 ринковими відносинами;

6) самозабезпечення культури через самостійні інститути (церква, освіта, творчі організації, індустрія культури) [2, 52].

Аналіз досліджень і публікацій. Проблематика дослідження культурного простору має міждисплінарний характер: концептуальні питання простору розглядали у свої працях С. Бабенко, О.Гриценко, Р. Кісь, О. Кравченко, М. Рябчук, О. Степанова, О. Суліменко. Питання культури і смислів культурного простору досліджували Є. Бистрицький, М. Жулинський, М. Закович, Т.Злобіна, I. Зязюн, Ж. Денисюк, В. Личковах, С. Кримський, Б. Парахонський, В. Полікарпова, М. Попович, В.Табачковський.

Мета роботи - проаналізувати концептуально етапи формування національного культурного простору, з огляду на паралелі загальнокультурного світового розвитку.

Виклад основного матеріалу. На сучасному етапі процес самозабезпечення культури здійснюється через самостійні інститути (церква, освіта, творчі організації, індустрія культури). У процесі саморегулячії культурної діяльності зазвичай виокремлюють три основні типи: субординація, координація та конкурентна змагальність. Субординація як підпорядкування єдиному началу має місце між столичним центром і периферією, центрами різного профілю та філіалами. Без координації, як узгодження дій учасників, не може бути налаштоване жодне мистецтво, що потребує злагодженої взаємодії багатьох виконавців (театр, кіно, телебачення тощо). Важливого значення набуває і принцип змагальності, що означає взаємодію незалежних суб'єктів і відбір найкращих через механізм, нейтральний щодо кожного учасника. Змагальність припускає усунення монополізму певних течій, шкіл або груп, спрямованих на збереження клановості, або бюрократизації та надмірної централізації. Зазвичай цей механізм реалізується як конкурс, за наслідками якого визначаються місця, присуджуються призи, премії.

До системи премій, що присуджуються за досягнення в різних галузях культури і науки, підключаються фінансові можливості як державних органів, так і ділових кіл, творчих об'єднань, суспільних інститутів тощо. Преміальна система, як правило, засновуються на конкурсному відборі кращих творів і в такому ракурсі втілює демократичні принципи (хоча численна критика упущень $\mathrm{i}$ зловживань $з$ боку комітетів 3 премій свідчить, що в налагодженні цієї системи виникає багато проблем). Преміальну систему в галузі культури можна розділити на такі варіанти: премії, що присуджуються державними органами, корпораціями, філантропічними об'єднаннями, науковими суспільствами й академіями, індивідуальними донорами та ін.

На початковому етапі свого становлення культурна політика багатьох економічно розвинених країн мала централізований характер, провідна роль відводилася державі. В основу такої політики 
було поставлено споживання культурного продукту, розширення мережі установ культури, які і створювалися, і спрямовувалися центральною владою.

У Новітній час формуються й інші моделі державної культурної політики. Приміром, після Другої світової війни (1939-1945рр.), із становленням постіндустріального суспільства, широкого розповсюдження набула ідея культурної демократії або рівного доступу всіх членів суспільства до здобутків культури. За цим лежали не тільки культурні, а й політичні цілі держави, яка хотіла впливати на населення за допомогою ушляхетнюючої ролі культури. До 60-х років XX ст. посилення впливу держави будь-якого політичного забарвлення у сфері культури пояснювалося "старим добрим" уявленням про цивілізаційну та ушляхетнюючу роль мистецтва і про демократизацію доступу до нього як до суспільного блага. Звідси пріоритетом культурної політики того часу стає щонайширший доступ населення до культурних цінностей через спеціальні освітні програми, безкоштовний доступ до музеїв, популяризація культури на державних теле- та радіоканалах і таке ін. Така тенденція зберігалася упродовж вельми тривалого часу, не зважаючи на певні приливи та відливи політичної й культурної моди" [3, 115].

Виходячи із наведеного вище, можемо стверджувати, що, з одного боку, тут культура i мистецтво трактуються як суспільне благо, що припускає забезпечення широкого доступу до нього силами державної політики, з іншого - піклується сама ідея самоиінності мистеитва.

Широке розуміння культури, прийняте багатьма урядами в той час, вміщувало освіту, засоби масової комунікації, туризм, соціальне обслуговування, виховання молоді. Зрозуміло, що управління такими різними та широкими сферами має реалізовуватися різними відомствами, для координації діяльності яких створювалися комітети із зв'язків між урядовими відомствами або парламентські комісії.

У 60-70-х роках у багатьох країнах з'явилися міністерства культури, проте галузь їхньої діяльності обмежувалася певними напрямами.

Разом із загальнодержавними установами значне місце в культурному житті зайняли неурядові організації як національні, так і міжнародні.

Різноманітні асоціації, письменницькі та журналістські організації, творчі колективи й асоціації, приватні видавництва, кіностудії, музеї і таке інше створюють широку мережу, що забезпечує культурну діяльність країни. Це відіграє важливу роль під час виділення коштів на розвиток галузі. Адже методи фінансування культури різні і визначити фактичні витрати на культуру й освіту важко. Тільки багаті країни можуть собі дозволити значні витрати на офіційно субсидійовану освіту, створення мережі культурних центрів тощо. Країни, позбавлені великих доходів, частіше покладаються на участь громадських організацій, іноземну допомогу, сприяння культурних агентств $\mathrm{i}$ різних місій з інших країн.

Проте, на початку 70-х років підхід, при якому культурі та мистецтву відводилася "ушляхетнююча суспільна роль", опинився під вогнем критики. Вважалося, що державна політика, яка заздалегідь визначає набір культурних цінностей і художніх форм, не відповідає принципам демократії, а є нав'язуванням більшості населення культури елітарної меншини, яка ігнорує більшість нових або нетрадиційних форм виразу та самосвідомості $[3,117]$.

Саме тому 3 початку 70-х років у культурній політиці більшості країн проявилася нова методологія демократизації культури: на зміну гаслу "культура для всіх" (культурна демократія) прийшло гасло демократизації культури - "культура для кожного". По-перше, це означало ширшу інтерпретацію поняття розвитку: воно вже не відображало тільки кількісний приріст, що створювався й управлявся центральними властями. Акцент перемістився в царину розвитку людських якостей в поєднанні з історичними, соціальними та культурними чинниками.

Головною метою стало посилення місцевої ідентичності й участь у культурному житті на місцевому рівні. По-друге, розширилися межі самого секторального поняття "культура". Увага приділялася не стільки споживанню культурного продукту, скільки особистій діяльності 3 виготовлення культурного продукту. По-третє, стало зрозумілим, що сучасний етап розвитку диктує переміщення центру культурної політики із центру (який "не встигає") до активнішого включення ресурсів регіонального та місцевого рівнів. А це, у свою чергу, припускало децентралізацію управління культурою.

Абсолютно природно, що 80-і роки стали десятиліттям нової моделі суспільного адміністрування на принципах децентралізації, яка стала певною формою партнерства державної влади та регіонів $[5,47]$.

Саме поняття "децентралізація" може тлумачитися по-різному. У культурній політиці, скажімо, цей термін може означати: 
1) децентралізацію культурної діяльності;

2) децентралізацію повноважень ухвалення рішень;

3) ухвалення рішень в галузі регіональної культурної політики повністю

належить регіональній адміністрації.

У США з середини 50-х років відбувався процес активізації втручання держави в регуляцію культурного життя. Особливо помітним він став у період правління президента Дж. Ф. Кеннеді, 3 розширенням системи органів, що здійснюють культурну політику під контролем як федерального уряду, так і конгресу. Запровадження американським урядом раніше не властивих йому функцій зустріло серйозну опозицію.

Проте після тривалих дебатів у конгресі та широкій дискусії у країні 1965 р. був створений Національний фонд мистецтв і гуманітарних наук як основний урядовий орган, який розподіляє державні субсидії, виробляє рекомендаційні програми в галузі культури і бере участь у проведенні культурної політики. Аналогічну офіційну та координуючу культурну політику за кордоном здійснює Інформаційне агентство США. У 80 -х роках пріоритетною моделлю державної політики США став "новий федералізм". Він запровадив тенденцію до децентралізації управління різними сферами діяльності, у тому числі і сфери культури, зменшення масштабів втручання держави у духовну сферу, перекладання завдань на різні ділові та суспільні інститути $[2,52]$.

У кінці 80-х - на початку 90-х років зароджується інструментальний підхід до культурної політики. Змістом такого підходу стало використання здатності культури служити різним політичним цілям і стратегіям, спрямованим на суспільний розвиток або вирішення соціальних проблем. Це було визнано в доповідях ЮНЕСКО ("Наше творче розмаїття", 1996 р.) і Ради Свропи ("Прагнення до цілісності", 1997 р.) за наслідками дослідження цілої низки країн, зокрема Франції та Великої Британії. Названі документи, як вже було зазначено, зробили певний внесок у розвиток концепції культури як засобу розвитку суспільства. Під цим розуміється передусім застосування культури для досягнення мети, безпосередньо 3 нею не пов'язаної - наприклад, використання театральних постановок і вечорів для дорослих для пропаганди здорового способу життя. Проте ретельніший аналіз свідчить, що будь-яка культурна діяльність i, відповідно, будь-які інвестиції в культуру мають неминучий соціально-економічний ефект і йдуть на благо суспільства в цілому" [3, 112].

Децентралізація й інструментальна культурна політика активізувала діяльність у культурній царині представників інших сфер: приватного сектора економіки (бізнесмени); державного управління, безпосередньо не пов'язаного 3 культурою. На думку шведського дослідника Гейра Вестхейма, за допомогою так званих "проектів змішаного використання" і співпраці приватні інвестори, державні адміністратори та представники культури намагалися досягти мети - кожний посвоєму. Приватні інвестори бажали знайти способи створення нового ринкового профілю i використовувати культуру для залучення спроможних клієнтів. Владні структури (не культурні, а керівники місцевого рівня) хотіли зробити свої регіони привабливішими; працівники культури та їхні організації використовували можливість прямого впливу на владу і розраховували отримати фінансовий ресурс як від приватних, так і державних інвесторів [4, 232].

У сучасних розвинених в економічному сенсі країнах різні сфери бізнесу, а також мережа філантропічних установ беруть на себе певну частку фінансової участі в регуляції культурної сфери: внески в художню культуру через створення культурних центрів, музеїв, виставок, інтер'єрів, запровадження грандів, стипендій і таке ін.

Така участь має передусім цілком певну економічну мету, пов'язану з такими критеріями: а) підвищення культурного рівня персоналу фірм і корпорацій; б) громадський престиж "патрона мистецтв" сприяє зміцненню віри в добротність фірми, призводить до зростання ії рентабельності та прибутку; в) сприяння процвітанню мистецтв так чи інакше збагачує духовне життя суспільства i знижує гостроту соціальної та політичної ангажованості; г) розширення культурної діяльності дає могутній стимул і для зростання ділової і соціальної активності, що і привело до створення "індустрії масової культури"; д) сприяння збалансування господарської та культурної сфер, підтримки оптимального рівня культури, не зважаючи на економічну обумовленість самого виробництва.

У такому контексті варто зазначити, що характерним зрушенням у механізмі комерційної регуляції художнього життя наприкінці XX -на початку XXI ст. стало широке підключення бізнесу до масової культури і навіть до різних напрямів контркультури (молодіжна, рухи "зелених", за "альтернативний спосіб життя"), руху національних меншин і таке ін. Безумовно, розвиток засобів масової комунікації помітно змінив комерційні пропорції. Простежується значне розширення видовищно-драматичних видів мистецтва й аудіовізуальних засобів комунікації. 3 одного боку, великий бізнес, повертаючись обличчям до творчих прагнень культурної еліти, послабляє критику на 
свою адресу з боку радикальної налаштованої творчої інтелігенції. 3 іншого боку, задовольняючи потреби у "масових ідолах" і нав'язуючи ці потреби, адаптує широкі верстви населення до функціонування в умовах суспільства масового споживання постіндустріальної доби.

У кінці XX ст. світові глобалізаційні й інтеграційні процеси поставили на порядок денний важливість діяльності у сфері регуляції культури не тільки з боку відомих наднаціональних структур $(\mathrm{OOH}$, ЮНЕСКО, Свропейського парламенту, різних міжнародних культурних і мистецьких організацій), а також транснаціональних корпорацій і міжнародних фондів, що поширюють свою діяльність на різні куточки земної кулі.

На зміну традиційній концепції економічного розвитку, згідно з якою економічне зростання розглядалося як поліпшення матеріальних умов життя населення, прийшла ширша концепція розвитку, де культурі відводиться одне з центральних місць у загальному процесі поліпшення якості життя. Як вже зазначалося, це знайшло своє відображення у "Плані дій з використання культурної політики в інтересах розвитку" - підсумковій декларації Стокгольмської конференції ЮНЕСКО (1998 р.). А Світовий банк на зустрічі 1999 року у Флоренції проголосив, що виділятиме позики країнам, що розвиваються, в тому випадку, якщо в їхніх програмах будуть задіяні культурні чинники.

Зрозуміло, що переміщення культурної політики до центру людського розвитку не здатне забезпечуватися лише політичними заявами, а має супроводжуватися розробкою нових концепцій управління сферою культури. Нині уявлення про те, що культурна політика є компетенцією передусім тих, хто ухвалює рішення на національному рівні, змінюються концепцію так званого "креативного управління" [5, 48].

У країнах Північної Європи децентралізація культури здійснювалася за першим типом. Для забезпечення доступу до високої культури на всій території і для всіх соціальних прошарків були створені спеціальні національні установи 3 організації гастролей у сфері театру і музики, обміну художніми виставками. Проте ефективність такої політики була обмеженою.

У Західній Європі, навпаки, формувалися тенденції переходу до децентралізації повноважень ухвалення рішень, проте форми і спрямування цього процесу були різними, залежно від політичних і адміністративних традицій. Наприклад, у Франції, децентралізація означала скорочення в центральних структурах, працівники яких були переміщені на регіональний рівень, до новостворених регіональних дирекцій у справах культури, що підлягали центру.

В інших європейських країнах, особливо в Швеції, Фінляндії, Данії, децентралізація означала передачу повноважень ухвалення рішень регіональним або місцевим виборним органам. При цьому держава зберігала відповідальність за основні напрями розвитку культурної політики та іiі найважливіші сфери.

Приміром, на державному рівні створювалися національні інститути культури, які стимулювали діяльність творчих працівників, здійснювалася міжнародна культурна політика, забезпечувалося збереження історико- культурної спадщини. Основною метою такої децентралізації стало чітке розмежування обов'язків між різними адміністративними рівнями.

Як зазначають Ф. Матарассо і Ч. Лендрі, "у 80-х роках політики і діячі мистецтва зацікавилися перспективами інвестицій в культуру. Виявилось, що пожвавлення культурної діяльності сприяе соціальному й економічному розвитку та процвітанню, у тому числі і на місцях.

Така участь має передусім цілком певну економічну мету, пов'язану з такими критеріями: а) підвищення культурного рівня персоналу фірм і корпорацій; б) громадський престиж "патрона мистецтв" сприяє зміцненню віри в добротність фірми, призводить до зростання ії рентабельності та прибутку; в) сприяння процвітанню мистецтв так чи інакше збагачує духовне життя суспільства i знижує гостроту соціальної та політичної ангажованості; г) розширення культурної діяльності дає могутній стимул і для зростання ділової і соціальної активності, що і привело до створення "індустрії масової культури"; д) сприяння збалансування господарської та культурної сфер, підтримки оптимального рівня культури, не зважаючи на економічну обумовленість самого виробництва.

У такому контексті варто зазначити, що характерним зрушенням у механізмі комерційної регуляції художнього життя наприкінці XX -на початку XXI ст. стало широке підключення бізнесу до масової культури і навіть до різних напрямів контркультури (молодіжна, рухи "зелених", за "альтернативний спосіб життя"), руху національних меншин і таке ін. Безумовно, розвиток засобів масової комунікації помітно змінив комерційні пропорції. Простежується значне розширення видовищно-драматичних видів мистецтва й аудіовізуальних засобів комунікації. 3 одного боку, великий бізнес, повертаючись обличчям до творчих прагнень культурної еліти, послабляє критику на свою адресу з боку радикальної налаштованої творчої інтелігенції. 3 іншого боку, задовольняючи 
потреби у "масових ідолах" і нав'язуючи ці потреби, адаптує широкі верстви населення до функціонування в умовах суспільства масового споживання постіндустріальної доби.

У кінці XX ст. світові глобалізаційні й інтеграційні процеси поставили на порядок денний важливість діяльності у сфері регуляції культури не тільки з боку відомих наднаціональних структур $(\mathrm{OOH}$, ЮНЕСКО, Європейського парламенту, різних міжнародних культурних i мистецьких організацій), а також транснаціональних корпорацій і міжнародних фондів, що поширюють свою діяльність на різні куточки земної кулі.

Загалом у сучасних умовах в розвинених постіндустріальних державах можна виокремити три найголовніші моделі взаємовідносин держави 3 культурною сферою: американську, британську і французьку. Вони відрізняються рівнем державного втручання у процеси підтримки культури, обсягами та механізмами недержавної підтримки митців і мистецьких заходів.

Американська модель відзначається децентралізацією підтримки культури, провідною роллю приватних спонсорів і фундацій, високим рівнем власної господарської ефективності культурномистецьких закладів.

Британська модель передбачає підтримку культури держави за принципом "витягнутої руки", розподілом бюджетних коштів через автономні недержавні й напівдержавні інституції.

Франиузька модель зорієнтована на потужну й централізовану підтримку національної культури.

Порівняльний аналіз специфічних особливостей таких трьох моделей державної політики в галузі культури дозволив відокремити їхні спільні риси: відстороненість держави від жорсткого впливу на об'єкти регулювання, їхня підтримка (фінансова, пільгова, податкова), стимулювання добродійності й меценатства, сприяння розвитку мережі недержавних організацій, що впливають на розвиток культури. Обов'язковою умовою ефективного функціонування сфери культури є досконала законодавча база, що відповідає вимогам часу, прийняття нормативних актів спеціального характеру, внесення змін і доповнень до чинних законів загального характеру.

Усі держави Європейського Союзу та США проводять добре продуману політику залучення до розвитку культури недержавних коштів. Тут є суттєві податкові пільги не лише для приватних спонсорів, а й для активного спонукання митців до їхнього пошуку, запроваджено різноманітні схеми так званих "доповнюючих гарантів". Приміром, отримавши певну суму від приватного спонсора, митець одержує і певну доплату від держави. 3 початку 90-х років XX ст. сфера культури щороку завдяки спонсорства одержувала приблизно 60 млн. фунтів стерлінгів у Великій Британії, майже 700 млн. франків у Франції, 300 млн. марок у Німеччині [6].

Висновки. На наш погляд, культура в сучасному суспільстві виступає й усвідомлюється не тільки як результат соціально-економічного та політичного розвитку, а й як необхідна умова, ключовий фактор розвитку, моральний стержень особистості й суспільства. Як об'єкт державного управління культура - це цілісний комплексний процес, головним орієнтиром якого є людина, іiі безумовний духовний (моральний $\mathrm{i}$ інтелектуальний) розвиток $\mathrm{i}$ вдосконалення. Адже стан культурного розвитку тієї чи іншої країни є одним із найбільш об'єктивних показників не тільки духовного здоров'я суспільства, але й повноти вирішення тих проблем, в першу чергу, політичних й економічних, які стоять перед ним. Політику держави в галузі культури доцільно розглядати як феномен єднання теорії та практики, що має свої особливості, пов'язані з живим безперервним культурним процесом, спрямованим на адаптацію іiі імперативів до соціокультурних реалій сучасності. Державна культурна політика має охоплювати культурні аспекти всіх державних програм економічного, екологічного, соціального, національного розвитку, а також фактора безпеки держави й особистості. В контексті зазначеного вище, змістом культурної політики є: виявлення пріоритетних напрямів розвитку культури відповідно до визначеного рівня культурного життя та реальних проблем; розроблення або ініціацію відповідно до пріоритетів різноманітних соціокультурних програм; підтримка та реалізація соціокультурних програм шляхом розподілу різного роду ресурсів.

\section{Лimepamypa}

1. Сенченко М.І. «Культурна революція» в Україні, або Управління деградацією. К.: МАУП, 2004. 312 с.

2. Стріха М. Українська держава і культура: спроба пошуків взаємодії на тлі світовог досвіду. Розбудова держави. 1996. № 11. С. 50-53

3. Сладкий Д. Національна ідентичність як фактор національної та міжнародної безпеки. Політичний менеджмент. 2008. № 2. С. 110-119.

4. Рубан Ю.Г. Концептуальні засади гуманітарного розвитку України: стратегічні пріоритети державної політики. Стратегічні пріоритети: [наук.-аналіт. щокварт. зб.]. 2009. № 3 (12). 248 с. 
5. Савельев В.В. Регионализация как условие повышения эффективности культурной политики. Отриентиры культурной политики. М.: ГИВЦ, 2003. С.46-61.

6. Adorno T. W. Kultur und Vervaltug. Szoilogishe Schrifien I. Frankfurt a. M. 1972.

\title{
References
}

1. Senchenko, M.I.( 2004).The "cultural revolution" in Ukraine, or the management of degradation. K .: MAUP [in Ukrainian].

2. Strika, M. (1996).Ukrainian state and culture: an attempt to search for interaction on the background of world experience. State building, 11, 50-53 [in Ukrainian].

3. Sweet, D. (2008). National identity as a factor of national and international security. Political management, 2, 110-119 [in Ukrainian].

4. Ruban, Yu.G. (2009). Conceptual principles of humanitarian development of Ukraine: strategic priorities of state policy. Strategic Priorities: [sci. Analyst. every quarter Sb.], 3 (12) [in Ukrainian].

5. Cavelev, V.V . (2003). Regionalization as a condition for increasing the effectiveness of cultural policy. Cultural Policymakers. M .: GIVS, 46-61 [in Ukrainian].

6. Adorno, T. W. (1972). Kultur und Vervaltug. Szoilogishe Schrifien I. Frankfurt a. M. [in English].

Стаття надійшла до редакиії 19.11.2018 p.

УДК 008: 130.2 "19/20"

\author{
Айгістова Аміна Аскярівна, \\ здобувач Київського національного університету \\ культури і мистецтв \\ ORCID 0000-0002-7927-0454
}

\section{СХІД І ЗАХІД У ЗВУКООБРАЗАХ СВІТОВОЇ ГАРМОНІЇ: ДИХОТОМІЯ ТА ДУАЛІЗМ КУЛЬТУР}

Метою статті $є$ дослідження специфіки моделювання звукообразів світової гармонії у філософськокультурологічних аспектах репрезентації проблематики «Схід-Захід» у музичній культурі. Методологія. Застосовано сукупність методів та методологічних підходів культурологічного, текстологічного, компаративного, культур-герменевтичного аналізу. Наукова новизна. Проведене дослідження дозволило, 3 одного боку, увиразнити конкретні змістові та мовно-виражальні напрями репрезентації звукообразів культур східного та західного цивілізаційного типу, а з іншого боку, констатувати доцентрові тенденції інтерпретації мовно-інтонаційного образу світу - від дихотомії до дуалізму східної та західної культур крізь призму відображення звукообразу тиші як художньо-музичного уособлення світової гармонії. Висновки. Сучасні глобально-цивілізаційні виклики актуалізують проблематику діалогу східної ї західної культур (азійського та європейського, північно-американського ареалу). 3 одного боку, загострюються культурні протиріччя, а 3 іншого, - пришвидшуються потоки міжкультурної комунікації за лініями східно-західного партнерства. Ці процеси знаходять безпосереднє виявлення в європейській музичній культурі, де філософсько-культурологічна специфіка репрезентації діалогової вісі «Схід-Захід» знаходить відображення у звукообразах як «художньозмістових концептах», що віддзеркалюють вектори протиставлення, віддалення, наближення та дуалізму культур. Останнє, виражається у звукообразах тиші, моделювання яких відповідає світоглядній парадигмі східного та західного мислення, уособлюючи ідеальний звуковий образ світової гармонії, що в умовах постмодерної парадигми є точкою культурного зближення двох антиномних світів.

Ключові слова: Схід-Захід, діалог культур, дихотомія культур, дуалізм культур, художній образ, звукообраз, гармонія, світова гармонія, звуковий образ світу.

Айгистова Амина Аскяровна, соискатель Киевского национального университета культуры $u$
искусствв
Восток и Запад в звукообразах мировой гармонии: дихотомия и дуализм культур
Цель работы. Целью статьи является исследование специфики моделирования звукообразов мировой
гармонии в философско-культурологических аспектах репрезентации проблематики «Восток-Запад» в
музыкальной культуре. Методология. Применена совокупность методов и методологических подходов
культурологического, текстологического, компаративного, культур-герменевтического анализа. Научная
новизна. Проведенное исследование позволило, с одной стороны, подчеркнуть конкретные содержательные и
выразительно-языковые направления репрезентации звукообразов культур восточного и западного
цивилизационного типа, а сдругой стороны - констатировать центростремительные тенденции интерпретации
интонационно-языкового образа мира - от дихотомии куализму восточной и западной культур сквозь призму

(C) Айгістова А. А., 2019 